\title{
Identification, tissue distribution and evaluation of brain neuropeptide Y gene expression in the Brazilian flounder Paralichthys orbignyanus
}

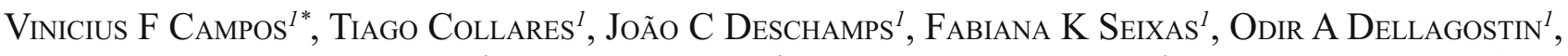 \\ Carlos Frederico C Lanes ${ }^{2}$, Juliana Sandrini ${ }^{3}$, Luis Fernando Marins ${ }^{3}$, Marcelo Okamoto ${ }^{4}$, \\ Luís A SAMPaio ${ }^{4}$ and Ricardo B Robaldo 5 \\ ${ }^{1}$ Centro de Desenvolvimento Tecnológico, Universidade Federal de Pelotas, CP 354, 96010-900, Pelotas, RS, Brazil \\ ${ }^{2}$ Faculty of Biosciences and Aquaculture, Bodø University College, NO-8049 Bodø, Norway \\ ${ }^{3}$ Laboratório de Biologia Molecular, Instituto de Ciências Biológicas, Universidade Federal do Rio Grande, \\ CP 474, 96201-900, Rio Grande, RS, Brazil \\ ${ }^{4}$ Laboratório de Piscicultura Estuarina e Marinha, Instituto de Oceanografia, Universidade Federal do Rio Grande, \\ CP 474, 96201-900, Rio Grande, RS, Brazil \\ ${ }^{5}$ Departamento de Fisiologia e Farmacologia, Instituto de Biologia, Universidade Federal de Pelotas, CP 354 , \\ 96010-900, Pelotas, RS, Brazil \\ *Corresponding author (Fax +55 53 3275-7351; Email, fariascampos@gmail.com)
}

\begin{abstract}
Neuropeptide Y (NPY) is one of the most potent stimulants of food intake in vertebrates, mammals and fish. However, the present knowledge about feeding behaviour in fish is still limited and based on studies in a few species. The Brazilian flounder Paralichthys orbignyanus is being considered for aquaculture, and it is important to understand the mechanisms regulating feeding in order to improve its performance in captivity. The objectives of this study were to clone NPY cDNA, evaluate the mRNA levels in different tissues of flounder, and also evaluate brain NPY expression to associate food intake with NPY expression levels. A $597 \mathrm{bp} \mathrm{NPY} \mathrm{cDNA} \mathrm{was} \mathrm{cloned} \mathrm{from} \mathrm{Brazilian} \mathrm{flounder} \mathrm{brain.}$ NPY expression was detected in all the peripheral tissues analysed. No significant differences were observed in brain NPY gene expression over $24 \mathrm{~h}$ after food intake at a temperature of $15 \pm 3^{\circ} \mathrm{C}$. No correlation was observed among plasma glucose, total protein, cholesterol, triglycerides and NPY expression levels during this $24 \mathrm{~h}$ period. On the other hand, mRNA levels were increased after two weeks of fasting at elevated temperatures. Our results suggest that NPY mRNA levels in Brazilian flounder are affected by temperature.
\end{abstract}

[Campos V F, Collares T, Deschamps J C, Seixas F K, Dellagostin O A, Lanes C F C, Sandrini J, Marins L F, Okamoto M, Sampaio L A and Robaldo R B 2010 Identification, tissue distribution and evaluation of brain neuropeptide Y gene expression in the Brazilian flounder Paralichthys orbignyanus; J. Biosci. 35 405-413] DOI 10.1007/s12038-010-0046-y

\section{Introduction}

Food intake in vertebrates is a complex process involving several neural pathways, in which neuropeptide Y (NPY) plays a key role. The stimulatory effects on food intake caused by central injections of NPY have been demonstrated in goldfish (Lopez-Patino et al. 1999) rainbow trout (Aldegunde and Mancebo 2006) and tilapia (Kiris et al. 2007). Immersion of African catfish fry into water containing NPY also stimulated feeding (Carpio et al. 2007), although this treatment has a stimulatory effect only for a short period of time.

NPY is a highly potent stimulant of growth hormone release in fish (Peng and Peter 1997), but growth enhancement can only be achieved when there is sufficient food available (Volkoff et al. 2005). Despite recent advances, our present knowledge of the regulation of feeding behaviour in fish is limited and based on a few species, and there is increasing evidence of species-specific differences (Volkoff et al. 2009). In goldfish, it was demonstrated that

Keywords. Food intake; gene expression; NPY; Paralichthys orbignyanus 
NPY mediates the action of ghrelin on feeding (Miura et al. 2006) and brain mRNA expression is significantly increased around mealtime in Atlantic cod (Kehoe and Volkoff 2007) and goldfish (Narnaware et al. 2000). An increase in brain NPY expression was observed after $72 \mathrm{~h}$ of food deprivation in goldfish, but immediately after feeding its expression was normalized (Narnaware and Peter 2001). Two weeks of food restriction significantly increased brain NPY mRNA levels in Winter skate (MacDonald and Volkoff 2009b), while in catfish, three weeks of fasting were needed to alter NPY expression in the brain (Silverstein and Plisetskaya 2000). On the other hand, in Atlantic salmon brain, NPY expression was not increased after six days of food deprivation (Murashita et al. 2009) and, as reported in Atlantic cod, seven days of fasting did not increase NPY gene expression (Kehoe and Volkoff 2007). NPY expression has also been detected in the intestine, liver, spleen, muscle and adipose tissue of fish (Liang et al. 2007) but little information about its function on these tissues is available.

According to Volkoff et al. (2009), the characterization of an appetite-regulating peptide must take into account the phylogeny of the fish, its physiological state as well as the environment it inhabits. The Brazilian flounder Paralichthys orbignyanus inhabits the estuarine and coastal waters from Rio de Janeiro (Brazil) to Mar del Plata (Argentina). Tolerance to a wide range of temperatures (Wasielesky et al. 1998), salinities (Sampaio and Bianchini 2002), as well as high concentrations of nitrogenous compounds (Bianchini et al. 1996) are characteristics that supported the initial studies related to its culture. More recently, studies related to reproduction (Radonic et al. 2007; Lanes et al. 2008; Sampaio et al. 2008), larviculture (Sampaio et al. 2007), expression of genes related to growth (Meier et al. 2009) and evaluation of transgenic potential (Lanes et al. 2009) showed the culture feasibility of this species. However, feeding regulation in this species has never been examined. The role of NPY in the regulation of feeding behaviour of the Brazilian flounder is not known and this information may be helpful to improve its culture.

The aims of this study were to clone a cDNA encoding Brazilian flounder NPY, examine NPY expression levels in different tissues and then assess its role on feeding behaviour by evaluating brain NPY mRNA expression over a $24 \mathrm{~h}$ period and after fasting by real-time reverse transcriptase polymerase chain reaction (RT-PCR).

\section{Materials and methods}

\subsection{Animals}

Fish used in this study were obtained by artificial spawning at the Laboratory of Marine Fish Culture at FURG (Brazil).
Two male flounder $(25.5 \pm 2 \mathrm{~cm}, 200 \pm 40 \mathrm{~g})$ were used to clone NPY cDNA and to evaluate tissue distribution. To evaluate $24 \mathrm{~h}$ brain NPY expression, animals were allocated to seven tanks with five animals in each tank, and were acclimated for two weeks in seawater. They were fed with commercial pellets (Supra Salmonídeos ${ }^{\mathrm{TM}} /$ Alisul/Brazil) containing $46 \%$ crude protein and $6 \%$ lipid once a day at the same time $(5 \mathrm{pm})$ under natural winter temperature $\left(15 \pm 3^{\circ} \mathrm{C}\right)$ and photoperiod (11L: 13D). Gene expression was measured at seven different times ( $0-10 \mathrm{~min}$ before food intake, 1, 2, 4, 6, 12 and $24 \mathrm{~h}$ after food intake). To evaluate the effect of fasting, fed and fasted groups of Brazilian flounder (28.2 \pm 4 $\mathrm{cm}, 250 \pm 45 \mathrm{~g}$ ) were sampled. Five fish (fed control) were sampled from a feeding tank with continuous feeding once a day. Subsequently, the feeding was stopped for two weeks, and five fish were sampled as a fasted group. Fish used in this experiment were acclimated and maintained at the same feeding regimen and photoperiod, and at a temperature of $23 \pm 2{ }^{\circ} \mathrm{C}$.

\subsection{Cloning of NPY cDNA}

Fish were anaesthetized in benzocain $\left(50 \mathrm{mg} \cdot \mathrm{l}^{-1}\right)$ and euthanatized by severing the spinal cord. Whole brains were immediately dissected out, frozen and stored in liquid nitrogen until use. Total RNA was isolated with TRIzol ${ }^{\circledR}$ Reagent (Invitrogen ${ }^{\mathrm{TM}}$, Carlsbad, USA). DNase treatment of RNA samples was conducted with a DNA-free ${ }^{\circledR}$ Kit (Ambion ${ }^{\mathrm{TM}}$, USA) following the manufacturer's protocol. First-strand cDNA was performed with $2 \mu \mathrm{g}$ of RNA using SuperScript ${ }^{\mathrm{TM}}$ III Reverse Transcriptase (Invitrogen $^{\mathrm{TM}}$, Carlsbad, USA) according to the manufacturer's protocol. Two degenerate primer sets NPY 01, 02, 03, 04 (see table 1) were designed to clone partial brain NPY cDNA sequences of Brazilian flounder based on the alignment of NPY sequences of other fish species. The PCR parameters were 40 cycles at $94^{\circ} \mathrm{C}$ for $30 \mathrm{~s}, 55^{\circ} \mathrm{C}$ for $30 \mathrm{~s}$ and $72^{\circ} \mathrm{C}$ for $1 \mathrm{~min}$, with an additional initial $1 \mathrm{~min}$ denaturation at $94^{\circ} \mathrm{C}$ and a 5 min final extension at $72^{\circ} \mathrm{C}$. PCR products were sequenced using a MegaBACE 500 automatic sequencer (Amersham Biosciences, USA). To perform 3'rapid amplification of cDNA end (RACE), total brain RNA was reverse transcribed to cDNA in the presence of oligo(dT) adaptor primer (AP) (table 1) also using SuperScript ${ }^{\mathrm{TM}}$ III RT (Invitrogen ${ }^{\mathrm{TM}}$, Carlsbad, USA) according to the manufacturer's protocol. For PCR, a forward gene-specific primer NPY $01 \mathrm{~F}$ and reverse AUAP primer were used with the following parameters: 40 cycles at $94^{\circ} \mathrm{C}$ for $30 \mathrm{~s}, 55^{\circ} \mathrm{C}$ for $30 \mathrm{~s}$ and $72^{\circ} \mathrm{C}$ for $1 \mathrm{~min}$, with an additional initial $1 \mathrm{~min}$ denaturation at $94^{\circ} \mathrm{C}$ and a $5 \mathrm{~min}$ final extension at $72^{\circ} \mathrm{C}$. The $3^{\prime}$-RACEPCR products were purified on an agarose gel with GFX ${ }^{\mathrm{TM}}$ PCR DNA and Gel Band Purification Kit and sequenced as described above. 
Table 1. Primers sequences used in this study

\begin{tabular}{|c|c|c|}
\hline Primers & Sequence $5^{\prime} \rightarrow 3^{\prime}$ & Use \\
\hline \multicolumn{3}{|l|}{ NPY primers } \\
\hline NPY $01 \mathrm{~F}$ & TGCATMCTARCTTRGTSAGCT & NPY cloning \\
\hline NPY 01R & GTGTCCAGAATCYCAGGACTG & NPY cloning \\
\hline NPY 03F & GACYCTGGGGYTCCTGCTGT & NPY cloning \\
\hline NPY 04R & ATGGGTYRTAWCTYGACTGTG & NPY cloning \\
\hline NPY real-time F & CACGTCATTTTCCTCCTGCAT & qRT-PCR and RT-PCR \\
\hline NPY real-time $\mathrm{R}$ & GCATAGCGGCTCGTAGAGGTA & qRT-PCR and RT-PCR \\
\hline \multicolumn{3}{|l|}{$3^{\prime} R A C E$ primers } \\
\hline oligo (dT) AP & GGCCACGCGTCGACTAGTACTTTTTTTTTTTTTTTTT & RACE \\
\hline AUAP & GGCCACGCGTCGACTAGTAC & RACE \\
\hline \multicolumn{3}{|l|}{$\beta$-actin primers } \\
\hline BAC real-time F & GACCCAGATCATGTTTGAGACCTT & qRT-PCR \\
\hline BAC real-time $\mathrm{R}$ & AGGGACAGCACAGCTTGGAT & qRT-PCR \\
\hline BAC semi F & AAGATCTGGCATCACACCTTCTA & RT-PCR \\
\hline BAC semi R & GGAGTCCATGACGATACCAGTG & RT-PCR \\
\hline
\end{tabular}

\subsection{Phylogenetic analysis}

Several nucleotide NPY coding sequences, including P. orbignyanus, were aligned using CLUSTAL X (Thompson et al. 1997) and a phylogenetic analysis was performed using the Phylogeny Inference Package PHYLYP 3.6 (Felsenstein 1997) and the maximum parsimony method (DNAPARS, for details see PHYLYP 3.6 manual). Xenopus laevis was used as an outgroup. A bootstrapping analysis using 1000 iterations was performed using SEQBOOT.

\subsection{Evaluation of NPY expression on flounder tissues by semi-quantitative RT-PCR}

Brain and peripheral tissues (liver, spleen, muscle, gill, intestine, heart, kidney, stomach and testis) were examined for NPY expression. Tissue collection, total RNA extraction, DNase treatment and cDNA synthesis were conducted as described in section 2.2. The same NPY primers (NPY 05 and 06, see table 1) used for evaluation of brain NPY expression over a $24 \mathrm{~h}$ period were also used for semiquantitative RT-PCR. For endogenous reference, $\beta$-actin (GenBank accession no. EU542580) primers BAC 03 and 04 were used (see table 1). PCR conditions for NPY were: 35 cycles at $94^{\circ} \mathrm{C}$ for $15 \mathrm{~s}, 60^{\circ} \mathrm{C}$ for $30 \mathrm{~s}$ and $72^{\circ} \mathrm{C}$ for $30 \mathrm{~s}$, with an additional initial $1 \mathrm{~min}$ denaturation at $94^{\circ} \mathrm{C}$ and a 5 min final extension at $72^{\circ} \mathrm{C}$. For $\beta$-actin, the conditions were: 35 cycles at $94^{\circ} \mathrm{C}$ for $30 \mathrm{~s}, 50^{\circ} \mathrm{C}$ for $30 \mathrm{~s}$ and $72^{\circ} \mathrm{C}$ for $1 \mathrm{~min}$, with an additional initial $1 \mathrm{~min}$ denaturation at $94^{\circ} \mathrm{C}$ and a 5 min final extension at $72^{\circ} \mathrm{C}$. PCR products for NPY were electrophoresed on a $2.5 \%$ agarose gel and for $\beta$-actin on a $1 \%$ agarose gel, both containing $0.5 \mu \mathrm{g} \mathrm{ml}^{-1}$ ethidium bromide.

\subsection{Biochemical parameters}

All fish of each group were anaesthetized at the same time with benzocain (50 mg. $\left.1^{-1}\right)$. Blood was collected from the first gill-arc artery, centrifuged (15 min at $1000 \mathrm{x} \mathrm{g}$ ), and plasma was frozen and stored in liquid nitrogen until analyses. The blood was treated with EDTA and potassium fluoride as an anticoagulant and anti-glycolytic, respectively. Plasma concentrations of glucose, total protein, triglycerides and cholesterol were measured through analytical enzymatic colorimetric kits (Doles Reagents ${ }^{\odot}$, Brazil), following the manufacturer's instructions.

\subsection{Evaluation of $24 h N P Y$ expression and NPY expres- sion after fasting by $q R T-P C R$}

After sampling blood to evaluate biochemical parameters for the $24 \mathrm{~h}$ experiment, brain collection, total RNA extraction, DNase treatment and cDNA synthesis were conducted as described in section 2.2. Real-time PCR was run on an Applied Biosystems 7300 Real-Time PCR System (Applied Biosystems $^{\mathrm{TM}}$, USA) using SYBR ${ }^{\circledR}$ Green PCR Master Mix (Applied Biosystems ${ }^{\mathrm{TM}}$, UK). Primers (table 1) for NPY 
and the endogenous reference $\beta$-actin were designed with the Primer Express v. 3.0 software (Applied Biosystems ${ }^{\mathrm{TM}}$, USA). Initial validation experiments were conducted to ensure that all primer pairs had equivalent PCR efficiencies. Amplification was carried out at the standard cycling conditions of $95^{\circ} \mathrm{C}$ for $10 \mathrm{~min}$, followed by 40 cycles at $95^{\circ} \mathrm{C}$ for $15 \mathrm{~s}, 60^{\circ} \mathrm{C}$ for $60 \mathrm{~s}$ followed by conditions to calculate the melting curve. All PCR runs for each cDNA sample were performed in triplicate. The real-time PCR data were analysed using the $2^{-\Delta \Delta \mathrm{Ct}}$ method, according to Livak and Schmittgen (2001) and the handbook of Chemistry guide of applied biosystems.

\subsection{Data analyses}

Gene expression and biochemical parameters over $24 \mathrm{~h}$ following a meal were compared using one-way ANOVA followed by the test of Tukey for multiple comparisons. Evaluation of gene expression in the fasting experiment was compared using the $t$ test. Significance was considered at $P<0.05$. All data are expressed as mean $\pm \mathrm{SEM}$.

\section{Results}

\subsection{NPY cloning}

Using RT-PCR coupled to 3'RACE-PCR, a 597 bp fragment of NPY cDNA was cloned from the brain of Brazilian flounder. This was deposited under GenBank accession no. FJ705358 (figure 1). The cloned fragment contained
$291 \mathrm{bp}$ of the final part of the open reading frame (ORF) of flounder NPY containing 25 amino acids that formed part of the signal peptide followed by 36 amino acids of mature peptide. The proteolytic processing site Gly-Lys-Arg was followed by 32 amino acids constituting a c-terminal peptide followed by a 3 'untranslated region (UTR) of $306 \mathrm{bp}$. The consensus phylogenetic tree (figure 2) revealed that the NPY of Brazilian flounder and that of other acanthomorph fish (Japanese flounder, grouper, European sea bass, Chinese perch and Atlantic cod) were grouped in the same cluster, whereas the NPY of channel catfish and the cyprinid fishes (goldfish and zebrafish) were grouped in another cluster. Mammalian and chicken NPY were grouped in different clusters and a frog was used as an outgroup.

\subsection{Evaluation of NPY gene expression in flounder tissues and brain}

The fragment corresponding to the NPY cDNA fragment was amplified in all analysed tissues (figure 3 ). Primers sets for NPY and $\beta$-actin had efficiencies of $104 \%$ and $107 \%$, respectively. No significant differences were observed in the NPY mRNA levels in the $24 \mathrm{~h}$ evaluation period (figure 4). Two weeks of food restriction were sufficient to increase the NPY mRNA levels in Brazilian flounder (figure. 5).

\subsection{Measurement of biochemical parameters}

The values of plasma glucose, cholesterol, total protein and triglycerides during the $24 \mathrm{~h}$ experiment are shown in

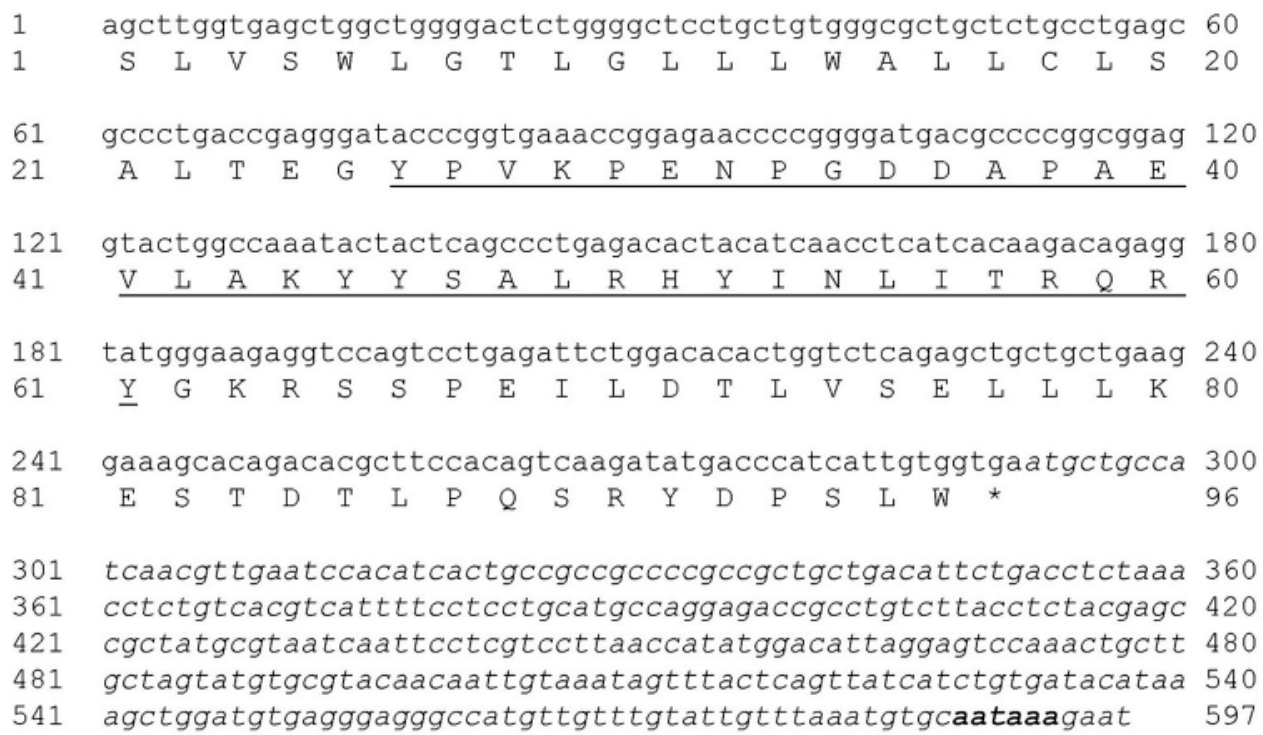

Figure 1. Partial NPY cDNA sequence cloned from Brazilian flounder brain (GenBank accession no. FJ705358) and deduced amino acid sequence. Deduced amino acid sequence of mature NPY is underlined. The asterisk indicates the stop codon. The $3^{\prime}$ untranslated region is in italics. The nucleotides corresponding to the polyadenylation signal (AATAAA) are in bold. 


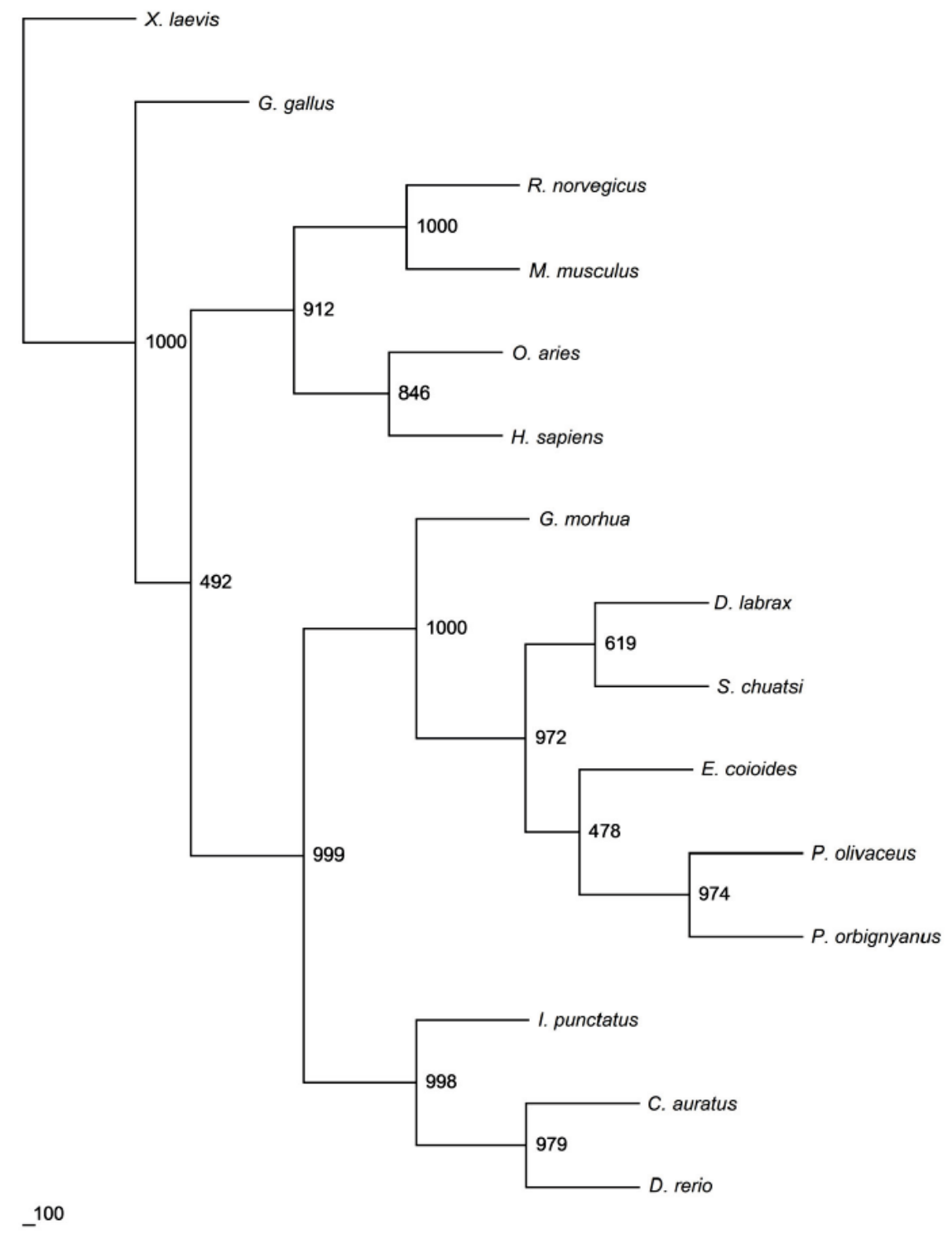

Figure 2. Phylogenetic tree of NPY coding sequences of Brazilian flounder (Paralichthys orbignyanus FJ705358), Japanese flounder (Paralichthys olivaceus AB055211), Atlantic cod (Gadus morhua AY822596), goldfish (Carassius auratus M87297), zebrafish (Danio rerio NM_131074), Chinese perch (Siniperca chuatsi EF554594), Channel catfish (Ictalurus punctatus AF267164), European sea bass (Dicentrarchus labrax AJ005378), grouper (Epinephelus coioides AY626561), frog (Xenopus laevis BC080115), chicken (Gallus gallus NM_205473), rat (Rattus norvegicus M20373), mouse (Mus musculus NM_023456), sheep (Ovis aries NM_001009452), human (Homo sapiens NM_000905).

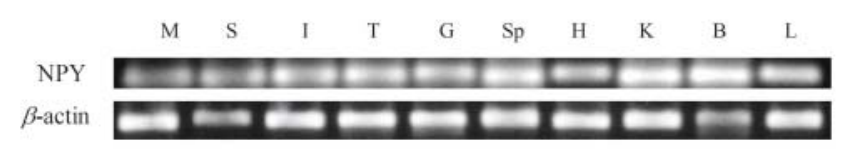

Figure 3. Semi-quantitative NPY mRNA expression in tissues of Brazilian flounder Paralichthys orbignyanus. M, muscle; S, stomach; I, intestine; T, testis; G, gill; Sp, spleen; H, heart; K, kidney; B, brain; L, liver. table 2. No significant association among these parameters and NPY expression level was detected $($ NPY $\times$ glucose, $P=0.6 ; \mathrm{NPY} \times$ total protein, $P=0.52 ; \mathrm{NPY} \times$ cholesterol, $P=0.22 ; \mathrm{NPY} \times$ triglycerides, $P=0.71)$.

\section{Discussion}

The NPY cDNA fragment of 597 bp from Brazilian flounder was cloned by the 3 'RACE-PCR method and contains a part 


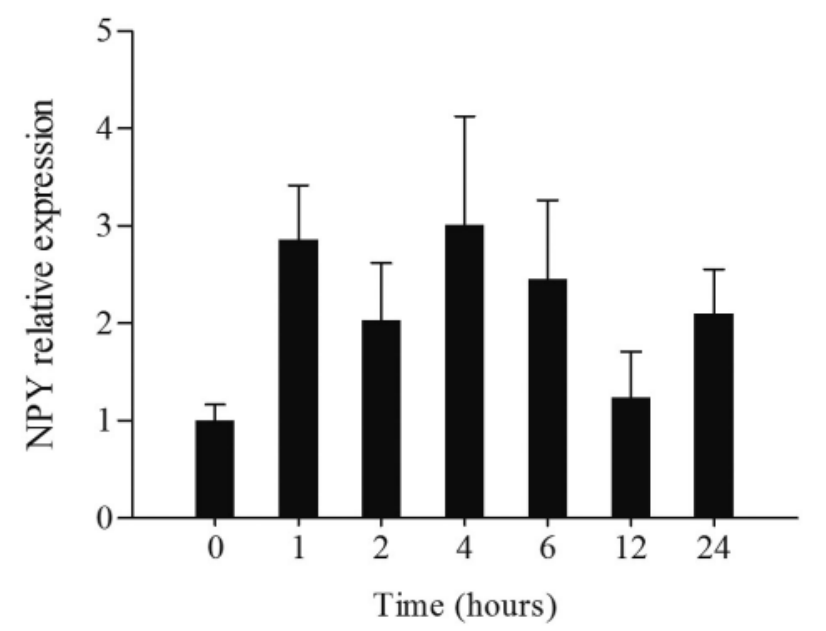

Figure 4. Evaluation of Paralichthys orbignyanus brain NPY expression over a $24 \mathrm{~h}$ period. Data are expressed as means $\pm \mathrm{SEM}$ $(N=5)$.

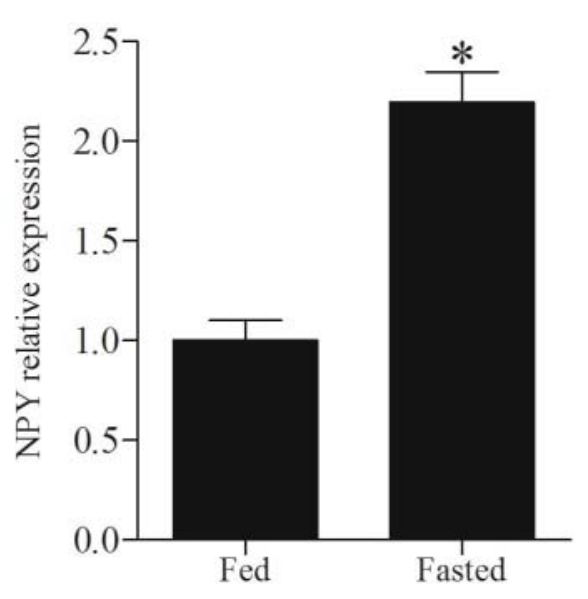

Figure 5. Evaluation of Paralichthys orbignyanus brain NPY expression in fed and fish fasted for two weeks. Data are expressed as means $\pm \operatorname{SEM}(N=5)$.

Table 2. Blood chemistry evaluation of Brazilian flounder Paralichthys orbignyanus over $24 \mathrm{~h}$ following a meal

\begin{tabular}{|c|c|c|c|c|c|c|c|}
\hline \multirow[b]{2}{*}{ Parameters } & \multicolumn{7}{|c|}{ Time (h) } \\
\hline & 0 & 1 & 2 & 4 & 6 & 12 & 24 \\
\hline $\begin{array}{l}\text { Glucose } \\
(\mathrm{mg} / \mathrm{dl})\end{array}$ & $33.1 \pm 5.4^{\mathrm{a}}$ & $43.5 \pm 1.1^{\mathrm{ab}}$ & $81.4 \pm 10.5^{\mathrm{bc}}$ & $87.6 \pm 11.5^{\mathrm{c}}$ & $67.2 \pm 11.7^{\mathrm{bc}}$ & $93.6 \pm 16.0^{c}$ & $113.7 \pm 14.7^{c}$ \\
\hline $\begin{array}{l}\text { Total protein } \\
(\mathrm{g} / \mathrm{dl})\end{array}$ & $4.1 \pm 0.6^{\mathrm{a}}$ & $4.7 \pm 0.5^{\mathrm{a}}$ & $6.2 \pm 1.1^{\mathrm{a}}$ & $7.1 \pm 1.4^{\mathrm{a}}$ & $5.3 \pm 1.1^{\mathrm{a}}$ & $3.3 \pm 0.3^{\mathrm{a}}$ & $24.9 \pm 0.4^{b}$ \\
\hline $\begin{array}{l}\text { Cholesterol } \\
(\mathrm{mg} / \mathrm{dl})\end{array}$ & $116.2 \pm 12.1^{\mathrm{bc}}$ & $96.5 \pm 8.2^{\mathrm{ab}}$ & $79.1 \pm 17.6^{\mathrm{ab}}$ & $77.7 \pm 7.4^{\mathrm{ab}}$ & $52.6 \pm 6.4^{\mathrm{a}}$ & $86.9 \pm 16.1^{\mathrm{ab}}$ & $162.9 \pm 18.9^{c}$ \\
\hline $\begin{array}{l}\text { Triglycerides } \\
(\mathrm{mg} / \mathrm{dl})\end{array}$ & $525.7 \pm 77.3^{\mathrm{a}}$ & $530.4 \pm 80.1^{\mathrm{a}}$ & $493.6 \pm 24.3^{\mathrm{a}}$ & $487.1 \pm 56.7^{\mathrm{a}}$ & $371.6 \pm 39.4^{\mathrm{a}}$ & $466.5 \pm 62.8^{a}$ & $615.6 \pm 28.5^{\mathrm{a}}$ \\
\hline
\end{tabular}

*Data are expressed as means \pm SEM $(N=5)$. Different letters indicate differences between means. Glucose data were transformed by $\log (\mathrm{X})$.

of coding region with $291 \mathrm{bp}$ lacking $9 \mathrm{bp}$ of the initial part of the ORF and the 3' UTR. However, the deduced amino acid of the mature peptide shares high identity with the NPY of other fish (table 3). In addition, the amino acid residue present at 14 position of the mature peptides NPY and peptide YY (PYY) or pancreatic peptide $\mathrm{Y}$ (PY) can be used to differentiate their sequences (Leonard et al. 2001). In the PYY or PY sequences, an invariable proline residue is present, while in the NPY sequences an alanine residue is present, except for trout NPY which has a treonine (Larhammar et al. 1993), and channel catfish which has a valine residue (Leonard et al. 2001). The deduced amino acid sequence for mature Brazilian flounder NPY determined in the present study has an alanine residue. The phylogenetic analysis of nucleotide sequences that encode NPY demonstrate that Brazilian flounder has high identity with the NPY of acanthomorph fish (composed of 99 aa). Mammalian, avian and amphibian were grouped in different clusters.

NPY expression was detected in several peripheral tissues as described by MacDonald and Volkoff (2009a).
Possible differences in NPY expression level among the peripheral tissues of Brazilian flounder might be the result of a differential regulation of NPY expression. Rats submitted to chronic food restriction had differentially affected NPY gene expression in the hypothalamus and liver, suggesting that NPY expression may also be differentially regulated in other tissues (Sucajtys-Szulc et al. 2008), while in fish it has not yet been demonstrated. Therefore, it may be risky to draw functional conclusions from anatomical studies in a single species (Soderberg et al. 2000).

In the present study, NPY gene expression in Brazilian flounder brain was examined. To our knowledge, this is the first time that NPY expression has been evaluated over a $24 \mathrm{~h}$ period. We show that NPY expression did not change within a $24 \mathrm{~h}$ period following a meal. These results are in contrast with previous studies in goldfish in which NPY expression levels were increased 1-3 h before food intake and decreased 1-3 $\mathrm{h}$ after food intake in the hypothalamus. However, in the optic tectum-thalamus, these levels were not increased and a weak increase was detected $1 \mathrm{~h}$ after 
Table 3. Amino acid identity (\%) between mature NPY from Brazilian flounder Paralichthys orbignyanus and other species ${ }^{\mathrm{a}}$

\begin{tabular}{lc}
\hline Species & Amino acid identity (\%) \\
\hline Paralichthys olivaceus & 97 \\
Epinephelus coioides & 97 \\
Siniperca chuatsi & 94 \\
Dicentrarchus labrax & 94 \\
Gadus morhua & 88 \\
Danio rerio & 88 \\
Ictalurus punctatus & 88 \\
Ovis aries & 88 \\
Carassius auratus & 86 \\
Xenopus laevis & 86 \\
Rattus & 83 \\
Mus musculus & 83 \\
Homo sapiens & 83 \\
Gallus gallus & 80 \\
\hline
\end{tabular}

${ }^{\text {a }}$ Calculated from the ClustalW multiple alignment as percentage of identical amino acids compared with P. orbignyanus NPY

food intake (Narnaware et al. 2000). These results suggest that post-prandial changes in NPY expression may be areaspecific. Besides, Kehoe and Volkoff (2007), using whole forebrain to evaluate gene expression, described increasing NPY mRNA levels around mealtime followed by a decrease $2 \mathrm{~h}$ later in Atlantic cod.

Indeed, exogenous factors such as temperature may result in a reduction in food intake and modify the digestive physiology in several fish species. In the winter flounder, hypothalamic NPY expression is not affected by fasting of two or even four weeks in the winter months, but these same starvation periods increase NPY levels in the summer (MacDonald and Volkoff 2009a). Here, we demonstrate that in Brazilian flounder, NPY mRNA levels increased after two weeks of fasting in the summer, as demonstrated in the winter skate (MacDonald and Volkoff 2009b). In our study, the low temperature $\left(15 \pm 3^{\circ} \mathrm{C}\right)$ during the $24 \mathrm{~h}$ experiment could increase the time required or food digestion and absorption, and this fact might have influenced the levels of NPY mRNA. This is supported by the increase in plasma glucose levels even $24 \mathrm{~h}$ after food intake, and also by the presence of a few pellets in the stomach. Hence, these low temperatures may not be sufficient to increase NPY expression. In contrast, low temperature can reduce food intake of Atlantic cod in captivity, but brain NPY mRNA levels do not appear to be influenced by this condition (Kehoe and Volkoff 2008).

Moreover, Kehoe and Volkoff (2007) have proposed that NPY can be a hunger signal prior to a meal and differences in NPY expression pattern among fish can be attributed to differences in the diet and digestive physiology, as well as susceptibility to stress. The Japanese flounder is very susceptible to transport and manipulation stress (Hur et al. 2007) and previous studies in rainbow trout (Doyon et al. 2003, 2006) demonstrate the influence of stress in NPY mRNA expression. Although all fish of each group were anaesthetized at the same time and were netted rapidly during sampling to minimize stress, it is possible that NPY levels might have been affected. Although not significant, the biochemical parameters, including glucose, increased at each sampling time, showing that digestion and absorption were in progress. However, correlations between biochemical parameters and brain NPY expression were not detected in the present study, showing that these biochemical variables could not be involved in NPY mRNA expression.

In summary, we demonstrate for the first time cDNA cloning of NPY from Brazilian flounder. NPY mRNA tends to be expressed mainly in the brain and is also expressed at different levels in several peripheral tissues, suggesting that NPY may be involved in other functions in these tissues. No significant correlations were found between NPY and biochemical parameters, and no significant differences were observed in brain NPY mRNA levels over a $24 \mathrm{~h}$ period after feeding at low temperatures. On the other hand, mRNA levels were increased after two weeks of fasting at elevated temperatures. Our results suggest that NPY mRNA levels in Brazilian flounder are affected by temperature.

\section{Acknowledgements}

This work was supported by MCT/CNPq-Edital Universal (\# 47438/2006-7). VFC is a student of the Graduate Program in Biotechnology at Universidade Federal de Pelotas and is supported by Brazilian CAPES. JCD, LAS, OAD and RBR are research fellows of CNPq. MHO is a graduate student of Aquaculture at Universidade Federal do Rio Grande and is supported by CAPES.

\section{References}

Aldegunde M and Mancebo M 2006 Effects of neuropeptide Y on food intake and brain biogenic amines in the rainbow trout (Oncorhynchus mykiss); Peptides 27 719-727

Bianchini A, Wasielesky W and Miranda K C 1996 Toxicity of nitrogenous compounds to juveniles of flatfish Paralichthys orbignyanus; Bull. Environ. Contam. Toxicol. 56 453-459

Carpio Y, Leon K, Acosta J, Morales R and Estrada M P 2007 Recombinant tilapia neuropeptide $\mathrm{Y}$ promotes growth and antioxidant defenses in African catfish (Clarias gariepinus) fry; Aquaculture 272 649-655

Doyon C, Gilmour K M, Trudeau V L and Moon T W 2003 Corticotropin-releasing factor and neuropeptide $\mathrm{Y}$ mRNA levels are elevated in the preoptic area of socially subordinate rainbow trout; Gen. Comp. Endocrinol. 133 260-271 
Doyon C, Leclair J, Trudeau V L and Moon T W 2006 Corticotropinreleasing factor and neuropeptide Y mRNA levels are modified by glucocorticoids in rainbow trout, Oncorhynchus mykiss; Gen. Comp. Endocrinol. 146 126-135

Felsenstein J 1997 An alternating least squares approach to inferring phylogenies from pairwise distances; Syst. Biol. 46 $101-111$

Hur J W, Park I S and Chang Y J 2007 Physiological responses of the olive flounder, Paralichthys olivaceus, to a series stress during the transportation process; Ichthyolog. Res. 54 32-37

Kehoe A S and Volkoff H 2007 Cloning and characterization of neuropeptide Y (NPY) and cocaine and amphetamine regulated transcript (CART) in Atlantic cod (Gadus morhua); Comp. Biochem. Physiol. Mol. Integr. Physiol. 146 451-461

Kehoe A S and Volkoff H 2008 The effects of temperature on feeding and expression of two appetite-related factors, neuropeptide $\mathrm{Y}$ and cocaine- and amphetamine-regulated transcript, in Atlantic cod, Gadus morhua; J. World Aquacult. Soc. 39 790-796

Kiris G A, Kumlu M and Dikel S 2007 Stimulatory effects of neuropeptide $\mathrm{Y}$ on food intake and growth of Oreochromis niloticus; Aquaculture 264 383-389

Lanes C F C, Okamoto M, Cavalcanti P V, Collares T, Campos V F, Deschamps J C, Robaldo R B, Marins L F et al. 2008 Cryopreservation of Brazilian flounder (Paralichthys orbignyanus) sperm; Aquaculture 275 361-365

Lanes C F C, Sampaio L A and Marins L F 2009 Evaluation of DNase activity in seminal plasma and uptake of exogenous DNA by spermatozoa of the Brazilian flounder Paralichthys orbignyanus; Theriogenology 71 525-533

Larhammar D, Blomqvist A G and Soderberg C 1993 Evolution of neuropeptide-y and its related peptides; Comp. Biochem. Physiol. C Pharmacol. Toxicol. Endocrinol. 106 743-752

Leonard J B K, Waldbieser G C and Silverstein J T 2001 Neuropeptide $\mathrm{Y}$ sequence and messenger RNA distribution in channel catfish (Ictalurus punctatus); Mar. Biotechnol. 3 $111-118$

Liang X F, Li G Z, Yao W, Cheong L W and Liao W Q 2007 Molecular characterization of neuropeptide $\mathrm{Y}$ gene in Chinese perch, an acanthomorph fish; Comp. Biochem. Physiol. B Biochem. Mol. Biol. 148 55-64

Livak K J and Schmittgen T D 2001 Analysis of relative gene expression data using real-time quantitative PCR and the 2(T)(Delta Delta C) method; Methods 25 402-408

Lopez-Patino M A, Guijarro A I, Isorna E, Delgado M J, AlonsoBedate M and de Pedro N 1999 Neuropeptide $Y$ has a stimulatory action on feeding behavior in goldfish (Carassius auratus); Eur. J. Pharmacol. 377 147-153

MacDonald E and Volkoff H 2009a Cloning, distribution and effects of season and nutritional status on the expression of neuropeptide Y (NPY), cocaine and amphetamine regulated transcript (CART) and cholecystokinin (CCK) in winter flounder (Pseudopleuronectes americanus); Horm. Behav. 56 $58-65$

MacDonald E and Volkoff H 2009b Neuropeptide Y (NPY), cocaine- and amphetamine-regulated transcript (CART) and cholecystokinin (CCK) in winter skate (Raja ocellata): cDNA cloning, tissue distribution and mRNA expression responses to fasting; Gen. Comp. Endocrinol. 161 252-261
Meier K M, Figueiredo M A, Kamimura M T, Laurino J, Maggioni R, Pinto L S, Dellagostin O A, Tesser M B et al. 2009 Increased growth hormone $(\mathrm{GH})$, growth hormone receptor (GHR), and insulin-like growth factor I (IGF-I) gene transcription after hyperosmotic stress in the Brazilian flounder Paralichthys orbignyanus; Fish Physiol. Biochem. 35 501-509

Miura T, Maruyama K, Shimakura S I, Kaiya H, Uchiyama M, Kangawa K, Shioda S and Matsuda K 2006 Neuropeptide Y mediates ghrelin-induced feeding in the goldfish, Carassius auratus; Neurosci. Lett. 407 279-283

Murashita K, Kurokawa T, Ebbesson L O E, Stefansson S O and Ronnestad I 2009 Characterization, tissue distribution, and regulation of agouti-related protein (AgRP), cocaine- and amphetamine-regulated transcript (CART) and neuropeptide Y (NPY) in Atlantic salmon (Salmo salar); Gen. Comp. Endocrinol. 162 160-171

Narnaware Y K and Peter R E 2001 Effects of food deprivation and refeeding on neuropeptide Y (NPY) mRNA levels in goldfish; Comp. Biochem. Physiol. B Biochem. Mol. Biol. 129 633-637

Narnaware Y K, Peyon P P, Lin X W and Peter R E 2000 Regulation of food intake by neuropeptide Y in goldfish; Am. J. Physiol. Regul. Integr. Comp. Physiol. 279 R1025-R1034

Peng C and Peter R E 1997 Neuroendocrine regulation of growth hormone secretion and growth in fish; Zool. Stud. 36 79-89

Radonic M, Muller M I, López A V, Bambill G A, Spinedi M and Boccanfuso J J 2007 Improvement in flounder Paralichthys orbignyanus controlled spawning in Argentina; Cienc. Mar. 33 187-196

Sampaio LA and Bianchini A2002 Salinity effects on osmoregulation and growth of the euryhaline flounder Paralichthys orbignyanus; J. Exp. Mar. Biol. Ecol. 269 187-196

Sampaio L A, Freitas L S, Okamoto M H, Louzada L R, Rodrigues R V and Robaldo R B 2007 Effects of salinity on Brazilian flounder Paralichthys orbignyanus from fertilization to juvenile settlement; Aquaculture 262 340-346

Sampaio L A, Robaldo R B and Bianchini A 2008 Hormoneinduced ovulation, natural spawning and larviculture of Brazilian flounder Paralichthys orbignyanus (Valenciennes, 1839); Aquaculture Res. $39712-717$

Silverstein J T and Plisetskaya E M 2000 The effects of NPY and insulin on food intake regulation in fish; Am. Zool. 40 296-308

Soderberg C, Wraith A, Ringvall M, Yan Y L, Postlethwait J H, Brodin L and Larhammar D 2000 Zebrafish genes for neuropeptide $\mathrm{Y}$ and peptide $\mathrm{YY}$ reveal origin by chromosome duplication from an ancestral gene linked to the homeobox cluster; J. Neurochem. 75 908-918

Sucajtys-Szulc E, Goyke E, Korczynska J, Stelmanska E, Rutkowski B and Swierczynski J 2008 Chronic food restriction differentially affects NPY mRNA level in neurons of the hypothalamus and in neurons that innervate liver; Neurosci. Lett. 433 174-177

Thompson J D, Gibson T J, Plewniak F, Jeanmougin F and Higgins D G 1997 The CLUSTAL_X windows interface: flexible 
strategies for multiple sequence alignment aided by quality analysis tools; Nucleic Acids Res. 25 4876-4882

Volkoff H, Canosa L F, Unniappan S, Cerda-Reverter J M, Bernier N J, Kelly S P and Peter R E 2005 Neuropeptides and the control of food intake in fish; Gen. Comp. Endocrinol. 142 3-19

Volkoff H, Xu M Y, MacDonald E and Hoskins L 2009 Aspects of the hormonal regulation of appetite in fish with emphasis on goldfish, Atlantic cod and winter flounder: notes on actions and responses to nutritional, environmental and reproductive changes; Comp. Biochem. Physiol. Mol. Integr. Physiol. 153 $8-12$

Wasielesky W J, Bianchini A and Miranda F K 1998 Tolerancia a la temperatura de juveniles de lenguado Paralichthys orbignyanus; Frente Maritimo 17 43-48

MS received 23 February 2010; accepted 5 May 2010

ePublication: 4 June 2010

Corresponding editor: RAPHAEL PINAUd 